\title{
Determinants of the EU Transport Market
}

\author{
Bibiana Bukova \\ Faculty of Operation and Economics of Transport and \\ Communication, University of Zilina \\ Zilina, Slovakia \\ bibiana.bukova@fpedas.uniza.sk
}

\author{
Eva Brumercikova \\ Faculty of Operation and Economics of Transport and \\ Communication, University of Zilina \\ Zilina, Slovakia \\ eva.brumercikova@fpedas.uniza.sk
}

\author{
Pavol Kondek \\ Faculty of Operation and Economics of Transport and Communication, University of Zilina \\ Zilina, Slovakia \\ pavol.kondek@gmail.com
}

\begin{abstract}
The article focuses on the determinants of transport market. As this problem area is very large, the article focuses only on the analysis and prognosis of the external EU transport market determinants. The chosen external transport market determinants processed in this article are the economic development of the world economy, specification of the EU regions and countries, the GDP and the population trend in the EU. In the conclusion of this article we show the relation between the transport trends and the $\mathrm{EU}$ industry development, price sensitivity change, transport service demand change and quality of supplementary carrier services.
\end{abstract}

Keywords—determinant, globalization, demand, transport, economy.

\section{INTRODUCTION}

Goods and services markets are constantly developing and rapidly changing their character and tools. On the other hand, customers are coming up with more and more specific requirements and expect high-quality and prompt information on the supply of goods and services.

Globalization as part of the economic processes affects three levels of the world economy: company level, state level and level of international trade. It significantly affects international relations, trade and of course transport. As Brumercik said [2] transport is becoming an important element of a complex system of international business that meets the needs of operators on the transport market. Determinants of the transport market can be divided into internal and external determinants. External determinants of the EU transport market include the economic development of the world economy, specifications of EU regions and states, development of GDP and development of population in the EU. Internal factors affecting the EU transport market are based on the EU transport policy, state of transport infrastructure and its development, new transport technologies and innovations, carrier flexibility and competitiveness. In the next part of this article we will analyze the external determinants of the EU transport market and we will define the perspective of further developments.

\section{DEVELOPMENT OF THE WORLD ECONOMY}

The world economy consists of the sum of national economies of individual countries, which are interconnected by international economic relations. The global economic development affects also the development of the EU economy. According to available data for the year 2014 (G8, G20 and EU-28 countries), the GDP per capita in US dollars ranges from USD 5.701 in India to USD 54.630 in the US. More detailed data are shown in Figure 1. Data were processed by The World Bank [5]

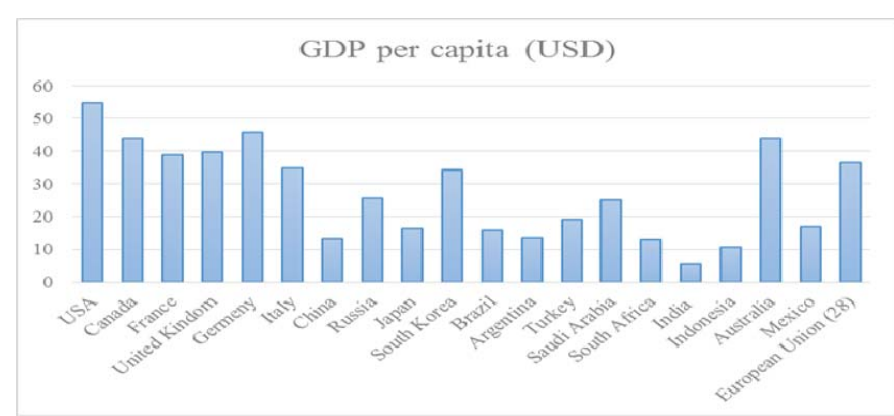

Figure 1. Graphical representation of GDP in selected countries in 2011

\section{A. Eurozone trade, import and export}

Eurostat present the result about external trade flows with extra EU- 28 follows [3]. The EU-28, China and the United States have been the three largest global players in international trade since 2004, when China passed Japan.

In 2014, the relation between exports and imports (the cover ratio) was particularly high in favour of exports into Russia and Norway, while in absolute terms China and Russia have had the largest annual trade surpluses since 2005. In 2014, the United States had the largest annual deficit.

Looking at the flows of exports and imports, the EU-28 had the second largest share of global exports and imports of goods in 2014: the EU-28's exports of goods were equivalent to $15.0 \%$ of the world total, and in 2014 they were surpassed for the first time since the EU was founded by those of China 
(15.5\%), but still ahead of the United States (12.2\%); the United States had a larger share of world imports (15.9\%) than either the EU-28 (14.8 \%) or China (12.9\%).

EU-28 international trade in goods with the rest of the world (the sum of extra-EU exports and imports) was valued at EUR 3517 billion in 2015. Both imports and exports increased in comparison with 2014, but this increase was larger for exports (EUR 88 billion) than for imports (EUR 35 billion). As a result, the EU-28's trade surplus increased from EUR 11 billion in 2014 to EUR 64 billion in 2015.

After experiencing a sharp fall in both exports and imports in 2009, the EU-28 saw its exports rise $58.7 \%$ over four years to a record level of EUR 1737 billion in 2013. Exports then fell $1.9 \%$ in 2014 before rising $5.1 \%$ to a new peak in 2015 of EUR 1791 billion. By contrast, the increase in imports after 2009 was $45.5 \%$ over three years to peak in 2012 at EUR 1 798 billion. Imports fell $6.2 \%$ in 2013 before stabilising (up $0.3 \%$ ) in 2014 and increasing by $2.0 \%$ in 2015, still below the value reached in 2012 .

Germany was by far the largest Member State in relation to extra EU-28 trade in 2015, contributing $28.2 \%$ of the EU28's exports of goods to non-member countries and accounting for almost one fifth (18.8 \%) of the EU-28's imports. The next three largest exporters, the United Kingdom (12.9\%), France (10.5\%) and Italy (10.4\%), remained the same as in 2014 (although France's extra-EU-28 exports surpassed those of Italy) and were the only other EU Member States to account for a double-digit share of EU-28 exports. The United Kingdom (15.2\%), the Netherlands (14.4\%), France $(9.5 \%)$ and Italy (8.9 \%) followed Germany as the largest importers of goods from non-member countries in 2015. The relatively high share for the Netherlands can, at least in part, be explained by the considerable amount of goods that flow into the EU through Rotterdam, which is the EU's leading sea port. The largest extra EU-28 trade surplus in goods, valued at EUR 179.4 billion in 2015, was recorded by Germany, followed by Italy (EUR 33.7 billion) and Ireland (EUR 29.3 billion).

\section{B. Analysis of the main trading partners}

Vincent BOURGEAIS noted [1] that, between 2005 and 2015, the development of the EU-28's exports of goods by the major trading partner varied considerably. Among the main trading partners, the highest growth rate was recorded for exports to China which more than trebled, while exports to South Korea and Brazil more than doubled. Exports to Japan and Russia grew more slowly and were approximately $30 \%$ higher in 2015 than they had been in 2005.

On the import side, between 2005 and 2015 the EU-28 saw a decrease in the value of its imports of goods from Japan (down 20 \%). The greatest increases were registered for imports from China and India which more than doubled.

The United States remained, by far, the most common destination for goods exported from the EU-28 in 2015, although the share of EU-28 exports destined for the United States fell from $28.0 \%$ of the total in 2002 to $16.7 \%$ in 2013 before recovering to $20.7 \%$ by 2015 . China was the second most important destination market for EU-28 exports in 2015 (9.5\% of the EU-28 total), followed by Switzerland (8.4\%). In 2015, Turkey overtook Russia to be the fourth largest destination for EU-28 exports of goods. The seven largest destination markets for the EU-28 exports of goods - China, the United States, Russia, Switzerland, Norway, Turkey and Japan — accounted for more than half (53.1 \%) of all EU-28 exports of goods.

The seven largest suppliers of the EU-28 imports of goods were the same countries as the seven largest destination markets for the EU-28 exports, although their order was slightly different. These seven countries accounted for a larger share of the EU-28's imports of goods than their share of EU28 exports of goods: nearly three fifths (59.8 \%) of all imports of goods into the EU-28 came from these seven countries. China was the origin for more than one fifth (20.3\%) of all imports into the EU-28 in 2015 and was the largest supplier of goods imported into the EU-28. The United States' share of EU-28 imports of goods (14.4\%) was around 6 percentage points lower than that of China, while the share of Russia (7.9\%), which was the third largest supplier of goods to the EU-28, was a further 6 percentage points smaller. In 2015, Turkey overtook Japan to be the sixth largest supplier of EU28 imports of goods.

In order to determine the development of the EU economy and the development of the transport market it is necessary to analyze the development of the EU transport market. The analysis was based on data for individual modes of transport and their transport performance in bil. tkm between 2000 and 2013. Individual transport performances are shown in the Figure 2. The data show that the greatest transport performances from the long-term perspective are achieved by road transport, followed by water transport (especially sea transport), rail, pipeline and air transport.

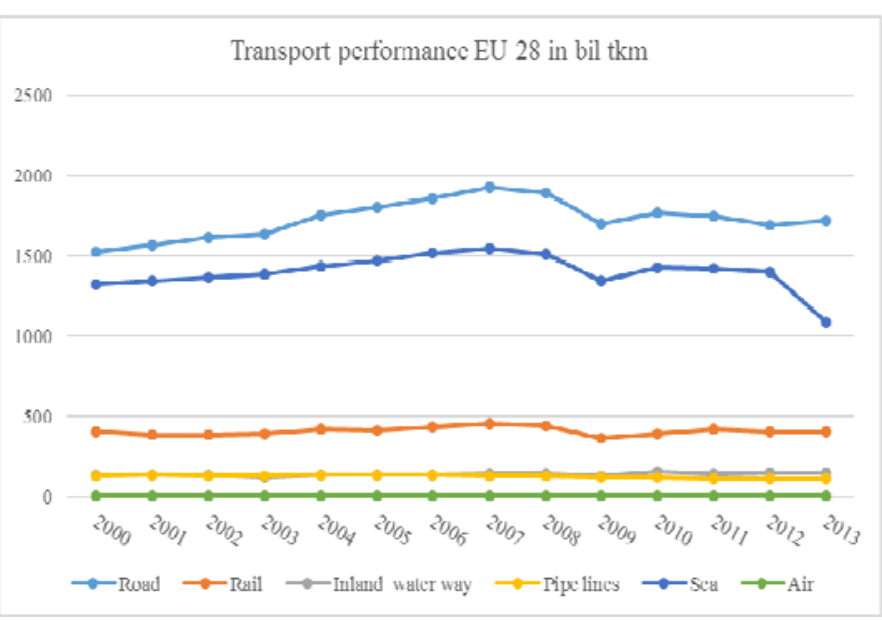

Figure 2: Graphical representation of the transport performance in individual modes of transport in the EU [3]

\section{DEVELOPMENT OF GDP}

GDP creation has an impact on freight traffic, as well as on public passenger transport. Several experts from the transport sector indicate that GDP growth by e.g. $10 \%$ may increase passenger transport - individual transport by 3.5\%, rail 
transport by $2.4 \%$, bus transport by $2.1 \%$ and air transport by $2 \%$. Gross capital formation and in particular its growth have a positive impact on freight transport. Stagnation and attenuation of the manufacturing and marketing sectors affect the activities of carriers. This is connected with the social factors of the transport market, lower population growth and aging, and especially the rise in unemployment across the EU.

Table 1 below shows the EU's GDP. Given the fact that during the period observed the EU expanded, GDP is shown per capita.

TABLE 1: Trend in the development of GDP in the EU countries

\begin{tabular}{|c|c|c|c|}
\hline Year & GDP in mil. $€$ & $\begin{array}{c}\text { Population in } \\
\text { mil. }\end{array}$ & $\begin{array}{c}\text { GDP per } \\
\text { capita in } €\end{array}$ \\
\hline 2000 & 9561468.10 & 487.0 & 19635.09 \\
\hline 2001 & 9959046.70 & 488.2 & 20401.58 \\
\hline 2002 & 10327309.00 & 489.0 & 21117.39 \\
\hline 2003 & 10494493.00 & 490.8 & 21383.52 \\
\hline 2004 & 11023755.10 & 492.7 & 22376.30 \\
\hline 2005 & 11516984.20 & 494.7 & 23280.64 \\
\hline 2006 & 12181943.90 & 496.5 & 24533.46 \\
\hline 2007 & 12914631.30 & 498.4 & 25911.74 \\
\hline 2008 & 12994979.50 & 500.4 & 25968.23 \\
\hline 2009 & 12254796.70 & 502.2 & 24402.90 \\
\hline 2010 & 12793540.00 & 503.2 & 25422.60 \\
\hline 2011 & 13179497.60 & 504.5 & 26124.17 \\
\hline 2012 & 13431767.50 & 504.1 & 26647.34 \\
\hline 2013 & 13548142.50 & 505.1 & 26821.90 \\
\hline 2014 & 13957764.40 & 506.9 & 27537.85 \\
\hline 2015 & 14625372.90 & 508.2 & 28779.28 \\
\hline
\end{tabular}

On the basis of the development of GDP per capita the trend of GDP development until 2020 was determined with a probability of $92.64 \%$ and $94.23 \%$. This trend is graphically displayed in Figure 3 below.

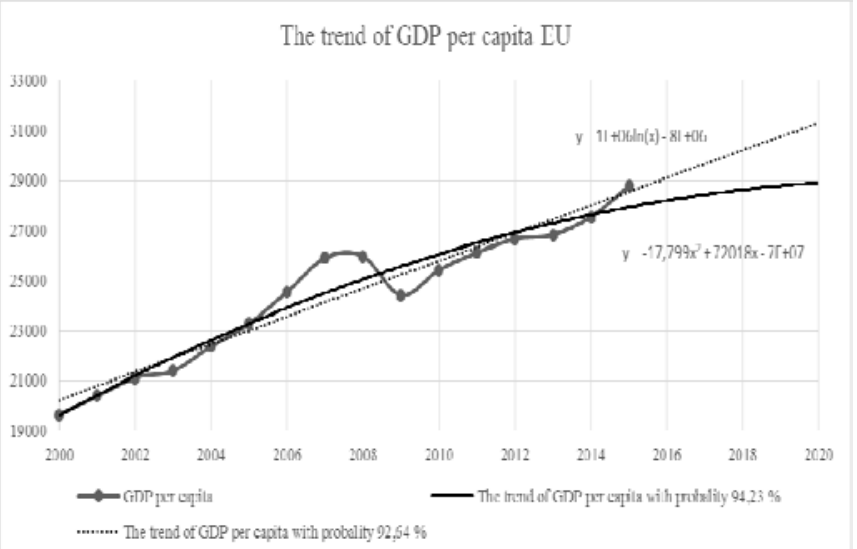

Figure 3: Development of GDP in the EU un-til 2020 (Source: authors)

Then we compared the development of GDP and the development of transport performance of the EU based on the data given in Table 2 below. For the purpose of comparison, data were recalculated per capita of the EU, since the EU expanded during the period analyzed. The result of this comparison was used to determine the development of goods transport depending on the GDP (see Figure 4). When determining the trend, we again used the highest probability, namely $33.45 \%$. This dependence was verified by the Fisher's rule, which showed that the transport performance is not dependent on the GDP. However, the result may be irrelevant given the level of government spendings and investments, which are part of the GDP. From that it follows that it is not possible to estimate the transport performance depending on the EU's GDP.

TABLE 2: Comparison of the GDP and the transport performance in the EU

\begin{tabular}{|c|c|c|c|c|}
\hline Year & $\begin{array}{c}\text { GDP per } \\
\text { capita }\end{array}$ & $\begin{array}{c}\text { Transport } \\
\text { performance } \\
\text { EU in bil. tkm }\end{array}$ & $\begin{array}{c}\text { Population } \\
\text { in mil. }\end{array}$ & $\begin{array}{c}\text { Transport } \\
\text { performance } \\
\text { per capita in } \\
\text { tkm }\end{array}$ \\
\hline 2000 & 19635.091 & 3513 & 487.0 & 7214.172 \\
\hline 2001 & 20401.582 & 3563 & 488.2 & 7298.975 \\
\hline 2002 & 21117.385 & 3628 & 489.0 & 7418.571 \\
\hline 2003 & 21383.524 & 3673 & 490.8 & 7484.086 \\
\hline 2004 & 22376.3 & 3880 & 492.7 & 7875.723 \\
\hline 2005 & 23280.644 & 3970 & 494.7 & 8025.031 \\
\hline 2006 & 24533.463 & 4090 & 496.5 & 8236.934 \\
\hline 2007 & 25911.737 & 4199 & 498.4 & 8424.815 \\
\hline 2008 & 25968.233 & 4118 & 500.4 & 8229.115 \\
\hline 2009 & 24402.897 & 3663 & 502.2 & 7294.108 \\
\hline 2010 & 25422.604 & 3863 & 503.2 & 7676.336 \\
\hline 2011 & 26124.172 & 3847 & 504.5 & 7625.457 \\
\hline 2012 & 26647.345 & 3769 & 504.1 & 7477.336 \\
\hline 2013 & 26821.897 & 3482 & 505.1 & 6893.480 \\
\hline & & \multicolumn{3}{|l}{} \\
\hline
\end{tabular}

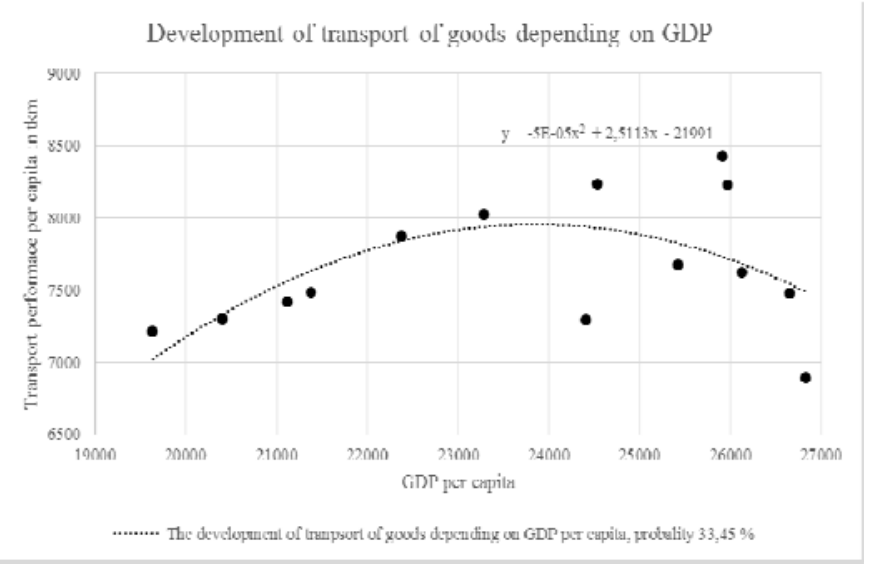

Figure 4: Development of goods transport depending on the GDP of the EU (Source: authors)

\section{POPULATION DEVELOPMENT}

The number of EU citizens over the age of 60 is currently increasing twice as fast as in the period before 2007 (by about two millions every year compared to one million in the past). Given the determined dependence of the development of the transport market on the population development, concrete data on the transport performance in passenger traffic and the development of population were processed in Table 3 below. 
TABLE 3: Comparing transport performance and EU population

\begin{tabular}{|c|c|c|c|}
\hline Year & $\begin{array}{c}\text { Transport } \\
\text { performance in } \\
\text { bil. pkm }\end{array}$ & $\begin{array}{c}\text { Population in } \\
\text { mil. }\end{array}$ & $\begin{array}{c}\text { Transport } \\
\text { performance per } \\
\text { capita in pkm }\end{array}$ \\
\hline 2000 & 5963 & 487.0 & 12245.40 \\
\hline 2001 & 6064 & 488.2 & 12422.39 \\
\hline 2002 & 6132 & 489.0 & 12538.78 \\
\hline 2003 & 6197 & 490.8 & 12626.97 \\
\hline 2004 & 6307 & 492.7 & 12802.11 \\
\hline 2005 & 6288 & 494.7 & 12710.68 \\
\hline 2006 & 6366 & 496.5 & 12820.62 \\
\hline 2007 & 6460 & 498.4 & 12961.25 \\
\hline 2008 & 6486 & 500.4 & 12961.16 \\
\hline 2009 & 6492 & 502.2 & 12927.48 \\
\hline 2010 & 6445 & 503.2 & 12807.14 \\
\hline 2011 & 6480 & 504.5 & 12844.54 \\
\hline 2012 & 6394 & 504.1 & 12685.09 \\
\hline 2013 & 6465 & 505.1 & 12799.07 \\
\hline
\end{tabular}

Using the data from Table 3 we determined the estimated development of passenger transport depending on the population of the EU, again with different probabilities (96.35\% and $84.76 \%)$. The result is graphically shown in Figure 5. The Fisher's rule confirmed the dependence of transport performance on population. The graph shows the development in the event of an increase of the EU population to 506 million people.

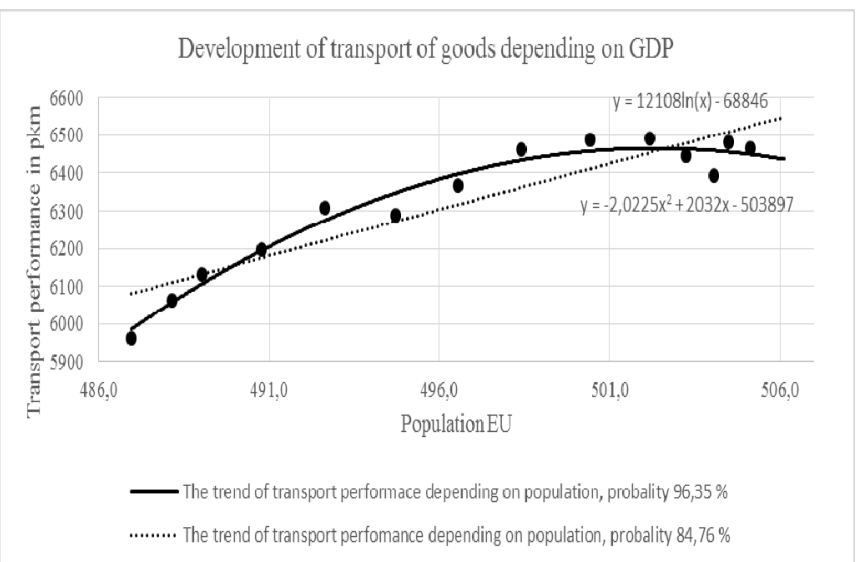

Figure 5: Development of passenger transport depending on the population of the EU

From that it follows that it is possible to estimate transport performance according to the estimated population. However, the problem remains that the European Union is constantly expanding and even at this time there are ongoing accession negotiations, e.g. with Serbia. Another possible influence on the transport market in public passenger transport

\section{CONCLUSION}

Globalisation has significantly affected traditional modes of transport, their organization and management, dynamics and strategy of further development. In the context of globalization processes, the development of transport has been long-term primarily influenced by factors such as the requirements of environmental protection, safety and reliability [4]. Other factors affecting the development of transport include liberalisation of the transport market and harmonisation of legislative, technical and operational conditions, new forms of international business and new forms of management technology, introduction of intelligent transport systems and the level of transport telematics. This article describes the development of the world economy. For the development of the freight transport market it is important to know the major trading partners of the EU. By knowing this, it is possible to determine which mode of transport will further develop. At present, road transport is still the mostly used mode of transport, which is unsatisfactory in view of the environment. Sea transport is booming because of trade relations with China or the US. A regression model of the dependence of the transport performance on GDP was made in this article and it was found and confirmed by the Fisher's rule that GDP does not affect the transport performance as predicted before the regression model. The reason could be the fact that GDP calculation includes government spending and investments that need not affect the transport performance. In the next part of the article we made the regression model of the impact of population on the passenger transport performance. The model confirmed that the development of population influences passenger transport, which is logical. In this case, however, it is not possible to estimate the development of passenger transport, as the EU is constantly expanding. In the past, regression models confirmed that the transport performances depend also on employment and the level of income of the population. It was also confirmed that in the case of increasing the purchasing power of the population the demand for rail passenger transport and bus transport declines and the demand for individual automobile transport increases. Thus, purchasing a car is more achievable for the EU citizens. EU transport policy talks about reducing the negative impact on the environment, which is why some cities and countries are giving rail transport and urban public transport advantages by increasing subsidies for these types of transport.

\section{References}

[1] Bourgeais, V.: International trade in goods in 2014 EU's top trading partners in 2014: the United States for exports, China for imports. Available

http://ec.europa.eu/eurostat/documents/2995521/6760204/627032015-AP-EN.pdf

[2] Brumercik, F., Sojcak, D.: Transport application of hybrid simulation, In.: Komunikacie. Volume 16, Issue 2, 2014, Pages 20-24. Univesity of Zilina. ISSN 13354205.

[3] External trade flows with extra EU- 28 follows. Available online: http://ec.europa.eu/eurostat/data/database- data ext_tl_intertrd

[4] Lalinská, J., Camaj, J., Nedeliaková, E.: Possibilities and solutions of compensation for delay of passenger trains and their economic impacts. In: Transport means 2015 : proceedings of the 19th international scientific conference : Kaunas University of Technology, Lithuania. - ISSN 1822-296X. -:pages 729-733

[5] The World Bank. Available online: http://data.worldbank.org/indicator/NY.GDP.MKTP.CD. 2015. 